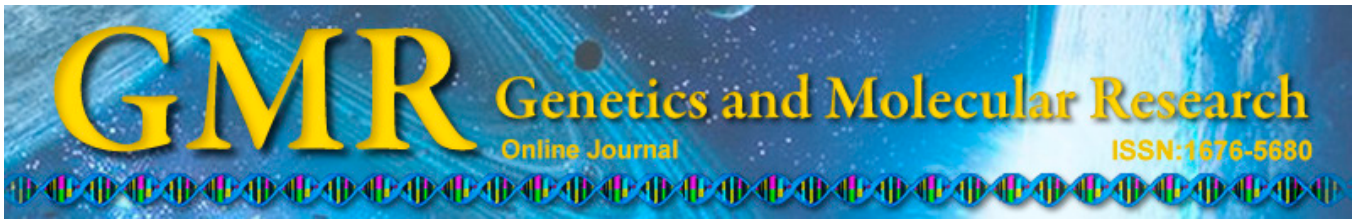

\title{
Role of interleukin-6 gene polymorphisms in the risk of coronary artery disease
}

\author{
K. Wang ${ }^{1}$, P.S. Dong ${ }^{1}$, H.F. Zhang ${ }^{1}$, Z.J. Li ${ }^{1}$, X.M. Yang ${ }^{1}$ and H. Liu ${ }^{2}$ \\ ${ }^{1}$ Department of Cardiovascular Medicine, \\ The First Affiliated Hospital of He'nan University of Science and Technology, \\ Luoyang, Henan, China \\ ${ }^{2}$ Emergency Department, 8680 Armed Police Army Hospital, Luoyang, \\ Henan, China \\ Corresponding author: P.S. Dong \\ E-mail: zhanghf588@126.com
}

Genet. Mol. Res. 14 (2): 3177-3183 (2015)

Received March 17, 2014

Accepted October 22, 2014

Published April 10, 2015

DOI http://dx.doi.org/10.4238/2015.April.10.29

\begin{abstract}
We conducted a case-control study to investigate the association between $I L-6-174 \mathrm{G}>\mathrm{C}$ and $-572 \mathrm{C}>\mathrm{G}$ polymorphisms and the risk of coronary artery disease (CAD). We genotyped IL-6 $-174 \mathrm{G}>\mathrm{C}$ and $-572 \mathrm{C}>\mathrm{G}$ in 402 patients with $\mathrm{CAD}$ and 402 control individuals. IL-6 -174 G>C (rs1800795) and $-572 \mathrm{C}>\mathrm{G}$ (rs1800796) alleles were detected by polymerase chain reaction-restriction fragment length polymorphism. Patients with CAD were more likely to have a smoking habit, diabetes, and hypertension, a high level of triglycerides, and low levels of total cholesterol and high- and low-density lipoprotein cholesterol. Multivariate regression analyses showed that subjects carrying the $I L-6-174 \mathrm{CC}$ genotype had a small but significant increased risk of CAD $(\mathrm{P}=0.004)$. Those carrying the $I L-6-174 \mathrm{G}>\mathrm{C}$ polymorphic variant had a slightly increased risk of CAD in both dominant and recessive models. However, we did not find significant association between the $I L-6-572 \mathrm{C}>\mathrm{G}$ polymorphism and risk of CAD. Moreover, a significant interaction was found between the $I L-6-174$ $\mathrm{G}>\mathrm{C}$ polymorphism, gender, and smoking habit. Our study, therefore, demonstrated that the $I L-6-174 \mathrm{G}>\mathrm{C}$ polymorphism is correlated with
\end{abstract}


CAD risk, and that this polymorphism shows interactions with both gender and smoking.

Key words: Interleukin-6; Polymorphism; Coronary artery disease

\section{INTRODUCTION}

Coronary artery disease (CAD) is a common and fatal chronic disease with high mortality. It is estimated that there have been 17.5 million deaths every year worldwide, with most of the cardiovascular events having occurred below the age of 75 years (Pignone et al., 2010). Previous studies have shown that CAD is caused by various factors, such as inflammation, gender, age, smoking, soy food intake, hypertension, and diabetes, as well as hereditary factors (Sayols-Baixeras et al., 2014; Yiannakouris et al., 2014; Yu et al., 2014). The underlying pathological mechanism of CAD is atheroma plaque instability, which is characterized by chronic inflammation caused by oxidized lipids adherent on the inner layer of the arterial wall. Recent studies have shown that inflammation-related genes might be correlated with CAD risk (Kroeger et al., 2012; Li et al., 2012; Xie et al., 2012).

Interleukin-6 (IL-6) is a proinflammatory and immunoregulatory cytokine found in diverse tissues, including fibroblasts, monocytes, adipocytes, and endothelial cells. IL-6 has a role in the genesis and maintenance of the inflammatory response (Balding et al., 2004). The polymorphisms of the $I L-6$ gene are associated with different levels of secreted protein according to the genotype. Two functional variants in the $I L-6$ gene, $-174 \mathrm{G}>\mathrm{C}$ (rs1800795) and $-572 \mathrm{C}>\mathrm{G}$ ( $\mathrm{rs} 1800796)$, have been widely investigated with relation to their association with risk of various disease (Mandić et al., 2013; Nie et al., 2014; Sung et al., 2014; Yang et al., 2014). These two gene polymorphisms may influence CAD susceptibility by altering gene regulation and protein expression (Morgan et al., 2006). Several studies show that $I L-6$ gene polymorphisms are associated with risk for $\mathrm{CAD}$, but different studies have reported conflicting results (Bhanushali and Das, 2013; Cui et al., 2013; Satti et al., 2013). Therefore, we conducted a case-control study to investigate the association between $I L-6-174 \mathrm{G}>\mathrm{C}$ and -572 $\mathrm{C}>\mathrm{G}$ polymorphisms and risk of $\mathrm{CAD}$.

\section{MATERIAL AND METHODS}

\section{Study population}

A total of 433 Chinese patients who were initially diagnosed with CAD were selected from the First Affiliated Hospital of He'nan University, Xinxiang, China. All patients were diagnosed by angiographic evidence of $\geq 70 \%$ stenosis of one major coronary artery, or $\geq 50 \%$ stenosis of the left main coronary artery. Patients who had autoimmune disease, congenital heart disease, severe kidney or liver disease, or malignancy were excluded from our study. In total, 402 patients were selected for our study, with a participation rate of $92.8 \%$. A total of 402 age- and gender-matched controls were collected from subjects who had taken a health examination as part of our study. Control subjects who suffered from CAD or any other heart disease were excluded from the study. All patients and control subjects signed a written informed consent form. Our study was approved by the Ethics Committee of the First Affiliated Hospital of He'nan University. 
A structured questionnaire was used to collect general information from patients and controls, including age, gender, smoking and drinking habits, hypertension, diabetes, and obesity. Total cholesterol (TC), triglycerides (TG), and low- and high-density lipoprotein cholesterol (LDL-C and HDL-C, respectively) levels were determined by serum analysis.

\section{Genotyping assays}

All study subjects were asked to provide $5 \mathrm{~mL}$ peripheral venous blood. Genomic DNA was extracted from peripheral venous blood samples using the TIANamp Blood DNA kit according to manufacturer instructions (Tiangen Biotech, Beijing, China). Genotyping analyses of $I L-6-174 \mathrm{G}>\mathrm{C}$ and $-572 \mathrm{C}>\mathrm{G}$ were performed by polymerase chain reactionrestriction fragment length polymorphism. The primers used for $I L-6-174 \mathrm{G}>\mathrm{C}$ and $-572 \mathrm{C}>\mathrm{G}$ were designed using the Sequenom Assay Design 3.1 software (Sequenom ${ }^{\circledR}$, San Diego, CA, USA) according to manufacturer instructions. The forward and reverse primers for $I L-6-174$ G $>$ C were 5'-TGA CTT CAG CTT TAC TCT TTG T-3' and 5'-CTG ATT GGA AAC CTT ATT AAG-3', respectively. The forward and reverse primers for $I L-6-572 \mathrm{C}>\mathrm{G}$ were 5 '-AGA TTC CAA GGG TCA CTT G-3' and 5'-AGA AGC AGA ACC ACT CTT C-3', respectively. The cycling program involved preliminary denaturation at $95^{\circ} \mathrm{C}$ for $5 \mathrm{~min}$, followed by 35 cycles of denaturation at $95^{\circ} \mathrm{C}$ for $30 \mathrm{~s}$, annealing at $62^{\circ} \mathrm{C}$ for $30 \mathrm{~s}$, extension at $72^{\circ} \mathrm{C}$ for $30 \mathrm{~s}$, and a final extension at $72^{\circ} \mathrm{C}$ for $10 \mathrm{~min}$. For quality control, $5 \%$ of subjects were randomly selected, and the results of repeated samples showed $100 \%$ concordance.

\section{Statistical analysis}

Continuous variables are reported as means $\pm \mathrm{SD}$, and categorical variables are reported as $\mathrm{N}$ of subjects (\%). The continuous variables and categorical variables were analyzed using the $\chi^{2}$ test. The Hardy-Weinberg equilibrium evaluation and between-group comparison of genotype distributions were carried out using the $\chi^{2}$ test. The odds ratios (OR) and corresponding $95 \%$ confidence intervals (CIs) were calculated by conditional logistic regression analysis and utilized to assess the potential association between genotype frequencies and risk of CAD. The homozygous genotypes of the three single nucleotide polymorphisms were taken as the reference group. All $\mathrm{P}$ values were two sided, and $\mathrm{P}<0.05$ was considered to be statistically significant. All statistical analyses were performed using the SPSS version 11.0 software (SPSS Inc., Chicago, IL, USA) for Windows.

\section{RESULTS}

This study included 402 patients with CAD and 402 healthy controls, with 232 men and 170 women in each group, respectively. The mean ages of patients and controls were 65.4 \pm 8.4 and $62.4 \pm 8.5$ years, respectively (Table 1 ). Patients with CAD were more likely to have a smoking habit, diabetes, and hypertension; and have a high TG level and low levels of TC, HDL-C, and LDL-C.

The genotype distributions of $I L-6-174 \mathrm{G}>\mathrm{C}$ and $-572 \mathrm{C}>\mathrm{G}$ in controls were in line with Hardy-Weinberg equilibrium, and $\mathrm{P}$ values were 0.24 and 0.12 , respectively. Genotype frequencies for $I L-6-174 \mathrm{G}>\mathrm{C}$ showed significant differences between patients and controls $\left(\chi^{2}=8.17, \mathrm{P}=0.017\right)$, while frequencies of $I L-6-572 \mathrm{C}>\mathrm{G}$ did not. Multivariate regression 
analyses showed that subjects carrying the $I L-6-174 \mathrm{CC}$ genotype had a small but significant increased risk of CAD, with an adjusted OR $(95 \% \mathrm{CI})$ of 1.71 (1.13-2.60) $(\mathrm{P}=0.004$; Table 2). Similarly, we found that those carrying the $I L-6-174 \mathrm{G}>\mathrm{C}$ polymorphism had a light increased risk of CAD in both dominant and recessive models, with adjusted ORs (95\%CIs) of 1.43 $(1.08-1.91)$ and $1.51(1.02-2.24)$, respectively (Table 2$)$. However, we did not find significant association between the $I L-6-572 \mathrm{C}>\mathrm{G}$ polymorphism and risk of CAD.

\begin{tabular}{|c|c|c|c|c|c|c|}
\hline Variables & Patients (N) & $\%$ & Controls $(\mathrm{N})$ & $\%$ & $t$ or $\chi^{2}$ & $P$ value \\
\hline Age, years (mean $\pm \mathrm{SD})$ & $65.4 \pm 8.4$ & & $64.9 \pm 8.2$ & & 0.85 & 0.2 \\
\hline \multicolumn{7}{|l|}{ Gender (\%) } \\
\hline Male & 232 & 57.6 & 232 & 57.6 & 0.00 & 1.00 \\
\hline Female & 170 & 42.4 & 170 & 42.4 & & \\
\hline BMI $\left(\mathrm{kg} / \mathrm{m}^{2}\right)$ & & $22.8 \pm 2.9$ & & $22.6 \pm 2.6$ & 1.03 & 0.15 \\
\hline \multicolumn{7}{|l|}{ Smoking (\%) } \\
\hline Ever & 154 & 38.2 & 131 & 32.6 & & \\
\hline Never & 248 & 61.8 & 271 & 67.4 & 4.82 & 0.03 \\
\hline \multicolumn{7}{|l|}{ Diabetes (\%) } \\
\hline Yes & 127 & 31.7 & 74 & 18.5 & & \\
\hline No & 275 & 68.3 & 328 & 81.5 & 30.95 & $<0.001$ \\
\hline \multicolumn{7}{|l|}{ Hypertension (\%) } \\
\hline Yes & 111 & 27.6 & 78 & 19.4 & & \\
\hline No & 291 & 72.4 & 324 & 80.6 & 8.85 & 0.003 \\
\hline $\mathrm{TC}(\mathrm{mM})$ & & $4.2 \pm 1.8$ & & $4.5 \pm 1.6$ & 2.57 & 0.005 \\
\hline $\mathrm{TG}(\mathrm{mM})$ & & $1.9 \pm 1.3$ & & $1.7 \pm 1.1$ & 2.35 & 0.01 \\
\hline LDL-C (mM) & & $2.7 \pm 1.2$ & & $2.9 \pm 1.4$ & 2.17 & 0.02 \\
\hline HDL-C (mM) & & $1.3 \pm 0.6$ & & $1.4 \pm 0.7$ & 2.17 & 0.02 \\
\hline
\end{tabular}

$\mathrm{BMI}=$ body mass index; $\mathrm{TC}=$ total cholesterol; $\mathrm{TG}=$ triglycerides; $\mathrm{LDL}-\mathrm{C}=$ low-density lipoprotein cholesterol; HDL-C $=$ high-density lipoprotein cholesterol.

Table 2. Genotype frequencies of $I L-6-174 \mathrm{G}>\mathrm{C}$ and $-572 \mathrm{C}>\mathrm{G}$ among young patients with $\mathrm{CAD}$ and control subjects, and their odds ratios.

\begin{tabular}{|c|c|c|c|c|c|c|c|c|c|}
\hline \multirow[t]{2}{*}{ SNP } & & \multirow{2}{*}{$\begin{array}{c}\text { Patients } \\
(\mathrm{N}=402)\end{array}$} & \multirow[t]{2}{*}{$\%$} & \multirow{2}{*}{$\begin{array}{l}\text { Controls } \\
(\mathrm{N}=402)\end{array}$} & \multirow[t]{2}{*}{$\%$} & \multirow[t]{2}{*}{ HWE } & \multicolumn{3}{|c|}{ OR $(95 \% \mathrm{CI})^{*}$} \\
\hline & & & & & & & Codominant model & Dominant model & Recessive model \\
\hline \multirow[t]{3}{*}{$-174 \mathrm{G}>\mathrm{C}$} & GG & 153 & 38.1 & 182 & 45.3 & & 1.0 (Ref.) & & \\
\hline & $\mathrm{GC}$ & 171 & 42.5 & 169 & 42.0 & & $1.32(0.96-1.82)$ & & \\
\hline & $\mathrm{CC}$ & 78 & 19.4 & 51 & 12.7 & 0.24 & $1.71(1.13-2.60)$ & $1.43(1.08-1.91)$ & $1.51(1.02-2.24)$ \\
\hline \multirow{3}{*}{$-572 \mathrm{C}>\mathrm{G}$} & $\mathrm{CC}$ & 176 & 43.8 & 192 & 47.8 & & 1.0 (Ref.) & & \\
\hline & $\mathrm{CG}$ & 187 & 46.5 & 181 & 45.0 & & $1.10(0.81-1.51)$ & & \\
\hline & GG & 39 & 9.7 & 29 & 7.2 & 0.12 & $1.47(0.86-2.56)$ & $1.17(0.88-1.56)$ & $1.42(0.84-2.42)$ \\
\hline
\end{tabular}

*Adjusted for age, gender, smoking, diabetes, hypertension, total cholesterol (TC), triglycerides (TG), low- and high-density lipoprotein cholesterol (LDL-C, HDL-C, respectively). SNP = single nucleotide polymorphism; HWE $=$ Hardy-Weinberg equilibrium; $\mathrm{OR}=$ odds ratio $\mathrm{CI}=$ confidence interval.

We further analyzed the interaction between the $I L-6-174 \mathrm{G}>\mathrm{C}$ polymorphism and demographic factors on the risk of CAD. As there was a relatively small sample size of patients with the -174CC genotype, we combined patients with -174CC and GC genotypes as one group for analysis. When compared with the -174GG genotype, we found that male patients, and those who were "ever smokers", who carried the IL-6 -174 GC + CC genotype had a higher risk of CAD, with ORs (95\%CIs) of 1.49 (1.01-2.20) and 2.12 (1.28-3.52), respectively (Table 3). Moreover, a significant interaction was found between the $I L-6-174 \mathrm{G}>\mathrm{C}$ 
polymorphism and gender and smoking habits, and the $\mathrm{P}$ values for the interaction were 0.03 and 0.04 , respectively. However, the $I L-6-174 \mathrm{G}>\mathrm{C}$ polymorphism had no interaction with age, body mass index, diabetes, hypertension, TC, TG, LDL-C, or HDL-C.

\begin{tabular}{|c|c|c|c|c|c|c|c|c|}
\hline \multirow[t]{2}{*}{ Subgroup } & \multicolumn{2}{|c|}{$I L-6-174 \mathrm{GG}$} & \multicolumn{2}{|c|}{$I L-6-174 \mathrm{GC}+\mathrm{CC}$} & \multirow[t]{2}{*}{$\chi^{2}$ value } & \multirow[t]{2}{*}{$P$ value } & \multirow[t]{2}{*}{ OR $(95 \% \mathrm{CI})$} & \multirow[t]{2}{*}{$\mathrm{P}$ for interaction } \\
\hline & Patient & $\overline{\text { Control }}$ & Patient & $\overline{\text { Control }}$ & & & & \\
\hline \multicolumn{9}{|c|}{ Age (years) } \\
\hline$<65$ & 75 & 93 & 126 & 107 & 3.48 & 0.06 & $1.46(0.96-2.22)$ & \\
\hline$\geq 65$ & 78 & 89 & 123 & 113 & 1.15 & 0.28 & $1.24(0.82-1.88)$ & 0.23 \\
\hline \multicolumn{9}{|l|}{ Gender } \\
\hline Male & 82 & 104 & 150 & 128 & 4.34 & 0.04 & $1.49(1.01-2.20)$ & \\
\hline Female & 71 & 66 & 99 & 104 & 0.31 & 0.58 & $0.88(0.56-1.40)$ & 0.03 \\
\hline \multicolumn{9}{|l|}{ BMI } \\
\hline$<23$ & 81 & 97 & 135 & 124 & 1.85 & 0.17 & $1.30(0.87-1.95)$ & \\
\hline$\geq 23$ & 72 & 85 & 114 & 96 & 2.55 & 0.11 & $1.40(0.91-2.17)$ & 0.35 \\
\hline \multicolumn{9}{|l|}{ Smoking } \\
\hline Ever & 61 & 54 & 93 & 77 & 9.56 & 0.002 & $2.12(1.28-3.52)$ & \\
\hline Never & 92 & 128 & 156 & 143 & 0.1 & 0.76 & $1.06(0.73-1.52)$ & 0.04 \\
\hline \multicolumn{9}{|l|}{ Diabetes } \\
\hline Yes & 47 & 36 & 80 & 38 & 2.61 & 0.11 & $1.61(0.86-3.00)$ & \\
\hline No & 106 & 146 & 169 & 182 & 2.19 & 0.14 & $1.28(0.91-1.80)$ & 0.11 \\
\hline \multicolumn{9}{|c|}{ Hypertension } \\
\hline Yes & 40 & 39 & 71 & 39 & 3.67 & 0.06 & $1.78(0.94-3.34)$ & \\
\hline No & 113 & 143 & 178 & 181 & 1.78 & 0.18 & $1.24(0.89-1.74)$ & 0.14 \\
\hline \multicolumn{9}{|l|}{$\mathrm{TC}(\mathrm{mM})$} \\
\hline$<4.3$ & 78 & 85 & 132 & 102 & 2.82 & 0.09 & $1.41(0.93-2.15)$ & \\
\hline$\geq 4.3$ & 75 & 97 & 117 & 118 & 1.52 & 0.22 & $1.28(0.85-1.94)$ & 0.19 \\
\hline \multicolumn{9}{|l|}{$\mathrm{TG}(\mathrm{mM})$} \\
\hline$<1.8$ & 72 & 97 & 118 & 118 & 2.16 & 0.14 & $1.35(0.89-2.04)$ & \\
\hline$\geq 1.8$ & 81 & 85 & 131 & 102 & 2.15 & 0.14 & $1.35(0.88-2.05)$ & 0.47 \\
\hline \multicolumn{9}{|c|}{ LDL-C (mM) } \\
\hline$<2.8$ & 71 & 86 & 116 & 105 & 1.94 & 0.16 & $1.34(0.87-2.06)$ & \\
\hline$\geq 2.8$ & 82 & 96 & 133 & 115 & 2.37 & 0.12 & $1.35(0.90-2.03)$ & 0.31 \\
\hline \multicolumn{9}{|c|}{ HDL-C (mM) } \\
\hline$<1.3$ & 73 & 88 & 122 & 103 & 2.96 & 0.09 & $1.43(0.93-2.19)$ & \\
\hline$\geq 1.3$ & 80 & 94 & 127 & 117 & 1.5 & 0.22 & $1.28(0.85-1.92)$ & 0.52 \\
\hline
\end{tabular}

$\mathrm{BMI}=$ body mass index; $\mathrm{TC}=$ total cholesterol $\mathrm{TG}=$ triglycerides $; \mathrm{LDL}-\mathrm{C} / \mathrm{HDL}-\mathrm{C}=$ low-/high-density lipoprotein cholesterol; $\mathrm{OR}=$ odds ratio; $\mathrm{CI}=$ confidence interval.

\section{DISCUSSION}

The identification of genes involved in the genetic predisposition or progression of disease has an important role in clinical practice and basic medical research. The use of genetic determinants for identifying high-risk populations and performance of targeted therapies based upon an individual's genetic make-up are well known clinical strategies. Many studies have investigated the genetic contribution of variants within the inflammatory cytokines to the development of CAD, but these have shown inconsistent results (Bhanushali and Das, 2013; Cui et al., 2013; Satti et al., 2013).

The $I L-6$ gene is located on chromosome $7 \mathrm{p} 21$. IL-6 itself is a multifunctional cytokine produced by immune and many non-immune cells, with roles both as an inflammatory mediator and also as a regulator of endocrine and metabolic function. Several studies have found that IL-6 might be involved in the development of CAD (Ghazouani et al., 2011; Phulukdaree et al., 
2013; Satti et al., 2013; Tong et al., 2013), but the results have been inconsistent. Therefore, we conducted a case-control study to investigate the relationship between the two common polymorphisms of the $I L-6$ gene and $\mathrm{CAD}$, in order to gain a more reliable conclusion.

Our study found that the $I L-6-174 \mathrm{CC}$ genotype was associated with an increased risk of $\mathrm{CAD}$, and this increased risk was also found using both dominant and recessive models. Our findings are in line with results from previous studies (Phulukdaree et al., 2013; Satti et al., 2013). Satti et al. (2013) reported that the $I L-6$ gene polymorphism was an independent risk factor for CAD. Another recent study conducted by Phulukdaree et al. (2013) reported that the $I L-6-174 \mathrm{G}$ allele influenced the levels of IL- 6 and the risk of CAD in South African Indians. However, two additional studies reported conflicting results (Ghazouani et al., 2011; Tong et al., 2013). Ghazouani et al. (2011) and Tong et al. (2013) reported that the $I L-6-174$ $\mathrm{G}>\mathrm{C}$ variant was not correlated with an increased risk of CAD in Tunisians or in a Chinese population, respectively. However, a recent meta-analysis of 50 studies suggested that the IL-6 -174 G>C polymorphism was positively associated with susceptibility to CAD (Yin et al., 2013), which is in line with the results of our study. The overall inconsistency of results between studies might be caused by the effects of different ethnicities, sample size, or case selection. Therefore, further ethnicity-specific studies are greatly needed to confirm our results.

In our subgroup analysis, we found that the $I L-6-174 \mathrm{G}>\mathrm{C}$ polymorphism had interactions with gender and with smoking habits. IL-6 is a pleiotropic cytokine and a mediator of the inflammatory response, and functions as both a proinflammatory and anti-inflammatory molecule. Previous studies have suggested that the $I L-6-174 \mathrm{G}>\mathrm{C}$ polymorphism has interactions with obesity and smoking (Panoulas et al., 2009; Franch-Chillida et al., 2010), which is partially inconsistent with the results from our study. Therefore, further large sample studies are greatly needed to confirm the association between $I L-6-174 \mathrm{G}>\mathrm{C}$ polymorphism and CAD risk.

In conclusion, the results from our study suggest a correlation between the $I L-6-174$ $\mathrm{G}>\mathrm{C}$ polymorphism and CAD risk, and that this polymorphism has interactions with gender and smoking. Our findings may be helpful in identifying individuals who are at increased risk for developing CAD.

\section{REFERENCES}

Balding J, Livingstone WJ, Pittock SJ, Mynett-Johnson L, et al. (2004). The IL-6 G-174C polymorphism may be associated with ischaemic stroke in patients without a history of hypertension. Irish J. Med. Sci. 173: 200-203.

Bhanushali AA and Das BR (2013). Promoter variants in interleukin-6 and tumor necrosis factor alpha and risk of coronary artery disease in a population from Western India. Indian J. Hum. Genet. 19: 430-436.

Cui Y, Zheng L, Jiang M, Jia R, et al. (2013). Circulating microparticles in patients with coronary heart disease and its correlation with interleukin-6 and C-reactive protein. Mol. Biol. Rep. 40: 6437-6442.

Franch-Chillida F, Nibali L, Madden I, Donos N, et al. (2010). Association between interleukin-6 polymorphisms and periodontitis in Indian non-smokers. J. Clin. Periodontol. 37: 137-144.

Ghazouani L, Abboud N, Ben Hadj Khalifa S, Added F, et al. (2011). -174G $>$ C interleukin-6 gene polymorphism in Tunisian patients with coronary artery disease. Ann. Saudi Med. 31: 40-44.

Kroeger CM, Klempel MC, Bhutani S, Trepanowski JF, et al. (2012). Improvement in coronary heart disease risk factors during an intermittent fasting/calorie restriction regimen: Relationship to adipokine modulations. Nutr. Metab. 9: 98.

Li Z, Jin D, Wu Y, Zhang K, et al. (2012). Increased serum interleukin-34 in patients with coronary artery disease. J. Int. Med. Res. 40: 1866-1870.

Mandić S, Sudarević B, Marczi S, Horvat V, et al. (2013). Interleukin-6 polymorphism and prostate cancer risk in population of Eastern Croatia. Coll. Anthropol. 37: 907-911.

Morgan L, Cooper J, Montgomery H, Kitchen N, et al. (2006). The interleukin-6 gene $-174 \mathrm{G}>\mathrm{C}$ and $-572 \mathrm{G}>\mathrm{C}$ promoter polymorphisms are related to cerebral aneurysms. J. Neurol. Neurosurg. Psychiatry 77: 915-917. 
Nie W, Xue L, Sun G, Ning Y, et al. (2014). Interleukin-6 -634C/G polymorphism is associated with lung cancer risk: a meta-analysis. Tumour Biol. 35: 4581-4587.

Panoulas VF, Stavropoulos-Kalinoglou A, Metsios GS, Smith JP, et al. (2009). Association of interleukin-6 (IL-6)$174 \mathrm{G} / \mathrm{C}$ gene polymorphism with cardiovascular disease in patients with rheumatoid arthritis: the role of obesity and smoking. Atherosclerosis 204: 178-183.

Phulukdaree A, Khan S, Ramkaran P, Govender R, et al. (2013). The interleukin-6 -147 g/c polymorphism is associated with increased risk of coronary artery disease in young South African Indian men. Metab. Syndr. Relat. Disord. 11: 205-209.

Pignone M, Alberts MJ, Colwell JA, Cushman M, et al. (2010). Aspirin for primary prevention of cardiovascular events in people with diabetes. J. Am. Coll. Cardiol. 55: 2878-2886.

Satti HS, Hussain S and Javed Q (2013). Association of interleukin-6 gene promoter polymorphism with coronary artery disease in Pakistani families. Sci. World J. 2013: 538365.

Sayols-Baixeras S, Lluís-Ganella C, Lucas G and Elosua R (2014). Pathogenesis of coronary artery disease: focus on genetic risk factors and identification of genetic variants. Appl. Clin. Genet. 7: 15-32.

Sung JW, Lee SH, Byrne CD, Chung PW, et al. (2014). High-sensitivity C-reactive protein is associated with the presence of coronary artery calcium in subjects with normal blood pressure but not in subjects with hypertension. Arch. Med. Res. 45: 170-176.

Tong Z, Li Q, Zhang J, Wei Y, et al. (2013). Association between interleukin 6 and interleukin 16 gene polymorphisms and coronary heart disease risk in a Chinese population. J. Int. Med. Res. 41: 1049-1056.

Xie F, Qian Q, Chen Z, Ma G, et al. (2012). Chitinase 3-like 1 gene-329G/A polymorphism, plasma concentration and risk of coronary heart disease in a Chinese population. Gene 499: 135-138.

Yang X, Feng L, Li C and Li Y (2014). Association of IL-6-174G $>$ C and $-572 \mathrm{C}>\mathrm{G}$ polymorphisms with risk of young ischemic stroke patients. Gene 539: 258-262.

Yiannakouris N, Katsoulis M, Trichopoulou A, Ordovas JM, et al. (2014). Additive influence of genetic predisposition and conventional risk factors in the incidence of coronary heart disease: a population-based study in Greece. $B M J$ Open 4: e004387.

Yin YW, Li JC, Zhang M, Wang JZ, et al. (2013). Influence of interleukin-6 gene -174G $>$ C polymorphism on development of atherosclerosis: a meta-analysis of 50 studies involving 33,514 subjects. Gene 529: 94-103.

Yu D, Zhang X, Xiang YB, Yang G, et al. (2014). Association of soy food intake with risk and biomarkers of coronary heart disease in Chinese men. Int. J. Cardiol. 172: e285-7. 